\title{
Fulvestrant: A Further Treatment Option for Patients with Metastatic Uterine Cancer?
}

\author{
Michael P. Lux ${ }^{a} \quad$ Evelyn M. Wenkel ${ }^{b} \quad$ Kai Beckmann ${ }^{a} \quad$ Matthias W. Beckmann ${ }^{a} \quad$ Falk Thiel $^{a}$ \\ a Department of Obstetrics and Gynecology, \\ ${ }^{\mathrm{b}}$ Insitute of Radiology, Universitätsklinikum Erlangen, Germany
}

Key Words

Uterine cancer, advanced · Fulvestrant · Endocrine therapy $\cdot$ Hepatic metastases

\section{Summary}

Background: Metastatic uterine cancer is notoriously difficult to treat, presenting a poor prognosis and a median survival time of less than 1 year. We present the successful use of the antiestrogen fulvestrant in an endocrine therapy-naïve patient with advanced uterine cancer. Case Report: A 64-year-old female presented with advanced uterine cancer $7.0 \times 6.0 \times 5.5 \mathrm{~cm}$ in size, with infiltration of the bladder. Previous chemotherapy and radiotherapy had been unsuccessful in preventing disease progression, and the patient developed hepatic metastases. As the tumor expressed a high level of estrogen receptor, treatment with fulvestrant $250 \mathrm{mg} / \mathrm{month}$ was initiated. Results: 25 months after commencing fulvestrant treatment, the tumor had decreased in size to $4.8 \times 3.5 \times 3.2$ $\mathrm{cm}$, and the hepatic metastases were no longer detectable. Throughout treatment, the patient maintained a Karnofsky performance index of $90 \%$. Conclusion: We suggest that fulvestrant may be an active and well-tolerated treatment option for patients with estrogen receptor-positive advanced uterine cancer.

\author{
Schlüsselwörter \\ Endometriumkarzinom, fortgeschrittenes - Fulvestrant . \\ Antihormontherapie · Lebermetastasen
}

\section{Zuzammenfassung}

Hintergrund: Das fortgeschrittene Endometriumkarzinom ist weiterhin eine Herausforderung für onkologisch tätige Ärztinnen und Ärzte. Die Patientinnen haben eine schlechte Prognose mit einer mittleren Überlebensdauer von weniger als einem Jahr. Im folgenden Fallbericht wird die erfolgreiche Therapie einer Patientin mit einem fortgeschrittenen Endometriumkarzinom mittels des Antiöstrogens Fulvestrant präsentiert. Fallbericht: Bei einer 64-jährigen Patientin wurde ein fortgeschrittenes Endometriumkarzinom mit einer Größe von 7,0 × 6,0 $\times$ $5,5 \mathrm{~cm}$ und einer Infiltration der Harnblase diagnostiziert. Eine durchgeführte Chemo- und Strahlentherapie konnte einen Progress des Primärtumors nicht verhindern und die Patientin entwickelte Lebermetastasen. Aufgrund einer Östrogenrezeptor-Expression des Tumors wurde die Behandlung mit Fulvestrant 250 mg/Monat eingeleitet. Ergebnisse: Nach Behandlung mit Fulvestrant über 25 Monate konnte eine Regression des Primärtumors auf $4,8 \times 3,5 \times 3,2 \mathrm{~cm}$ erreicht werden. Die hepatische Metastasierung war nicht mehr nachweisbar. Während des gesamten Therapiezeitraumes blieb der Karnofsky-Index der Patientin bei $90 \%$. Schlussfolgerung: Somit kann die Therapie mit Fulvestrant eine effektive und nebenwirkungsarme Behandlungsoption für Patientinnen mit einem östrogenrezeptorpositiven, fortgeschrittenen Endometriumkarzinom darstellen.

\begin{tabular}{ll}
\hline KARGER & @ 2006 S. Karger GmbH, Freiburg \\
Fax +49 7614520714 & Accessible online at: \\
$\begin{array}{l}\text { E-mail Information@Karger.de } \\
\text { www.karger.com }\end{array}$ & www.karger.com/onk
\end{tabular}

www.karger.com
Dr. med. Michael Patrick Lux 


\section{Introduction}

Uterine cancer is the most common malignant neoplasm of the female genital tract and the 4th most common cancer in women [1]. Early-stage uterine cancer can usually be managed effectively [2]. However, advanced or recurrent uterine cancer is difficult to treat and shows a poor prognosis, with a median survival time of less than 1 year [3]. Recommended treatment comprises surgery (where appropriate) along with radiotherapy and chemotherapy [4], but the low response rates observed in the advanced setting reflect a need for new therapies.

Uterine cancer that expresses the estrogen (ER) and/or progesterone receptor $(\mathrm{PgR})$ may be responsive to endocrine therapy [5]. Hormonal agents, in particular progestins [6], have been used to treat endometrial cancer for more than 40 years, although until recently response rates have remained unchanged [7]. Phase II studies have shown that the estrogen antagonist arzoxifene has antitumor activity in advanced endometrial cancer, demonstrating a response rate of $28 \%$ in 32 patients [8]. Preliminary evaluation of the non-steroidal aromatase inhibitor letrozole has also indicated that it may have potential in the treatment of endometrial cancer as well as low-grade endometrial stromal sarcoma [9].

The last few years have seen significant advances in the endocrine treatment of advanced breast cancer, one example being the introduction of the new ER antagonist fulvestrant (Faslodex ${ }^{\circledR}$, AstraZeneca GmbH, Wedel, Germany) [10]. Such endocrine therapies may have a role to play in the treatment of other hormone-dependent cancers. Here, we report the successful use of fulvestrant in the treatment of a patient with ER-positive metastatic uterine cancer.

\section{Case Report}

This report follows the progress of a 64-year-old patient, who first presented in June 2003, and was diagnosed with advanced uterine cancer (cT4 N1 M0) by curettage. She had concomitant hyperthyroidism, varicosis and controlled hypertension. The following month (July 2003), an oophorectomy, staging laparotomy and lymph node biopsy of the aortocaval area were performed at the Women's Hospital of Erlangen University. Subsequent to surgery, in September 2003, a computed tomography (CT) scan showed a tumor of $7.0 \times 6.0 \times 5.5 \mathrm{~cm}$ in size, and the laparotomy revealed 2 positive aortocaval lymph nodes, along with infiltration of the primary tumor into the bladder (fig. 1 a). Histological examination presented a tumor with partial squamous, partial mucinous and partial endometroid differentiation (FIGO IVa, pT4a pN1 G2 R2). The same month, the patient received 1 cycle of docetaxel chemotherapy $\left(100 \mathrm{mg} / \mathrm{m}^{2}\right)$ together with external beam radiotherapy to the pelvis and lymph drain region (median dose of 36.0 Gy to lumbar vertebra L1). This was followed by a further cycle of docetaxel chemotherapy $\left(100 \mathrm{mg} / \mathrm{m}^{2}\right)$ along with radiotherapy to the pelvis (up to a median dose of 50.4 Gy to L5) in addition to a small volume boost irradiation of the para-aortic region (up to $40.3 \mathrm{~Gy}$ ).

In October, the patient received intracavity high-dose rate (HDR) brachytherapy (median dose of $24.0 \mathrm{~Gy}$ in 6.0 Gy fractions). The following January, the patient received 2 cycles of docetaxel chemotherapy $\left(100 \mathrm{mg} / \mathrm{m}^{2}\right)$. Docetaxel was administered as first-line chemotherapy treatment analogous to the Uterus-4 study $[5,11]$, rather than the more commonly used platinum-based regimens. The choice for docetaxel was based on good personal experience with this regimen. At the first evaluation after chemotherapy (February 2004), the CT scan showed stable disease (fig. $1 \mathrm{~b}$ ). The scan showed an inhomogeneous enhancing uterine tumor that was $6.6 \times 6.1 \times 5.7 \mathrm{~cm}$ in size, and a hypodense hepatic lesion indicating possible metastasis $(1.5 \times 1.3 \times 1.0 \mathrm{~cm}$ in the liver segment VII $)$. Immunohistochemical analysis of the tumor had revealed a high level of expression of ER, and in light of this (and the suspected liver metastasis), the decision was made to initiate fulvestrant therapy at the standard dose of $250 \mathrm{mg} / \mathrm{month}$ (off-label use), commencing at the end of March 2004. Prior to this, ultrasonography revealed a stable pelvic tumor of $6.5 \times 6.1 \times$ $4.5 \mathrm{~cm}$ in size. The first evaluation of the tumor by ultrasonography, after the initiation of fulvestrant (May 2004), revealed a stable pelvic tumor that was $5.0 \times 5.2 \times 3.7 \mathrm{~cm}$ in size. The second (June 2004) and third (August 2004) evaluations (both by ultrasonography) revealed the tumor to be $6.1 \times 4.4 \times 3.8 \mathrm{~cm}$ and $3.5 \times 3.3 \times 4.0 \mathrm{~cm}$ in size, respectively, with no evidence of liver metastases or suspect structures.

The 4th evaluation (November 2004) was performed by CT scan, and once again showed that the uterine tumor had decreased to $6.0 \times 5.0 \times 4.3$ $\mathrm{cm}$ and that the hepatic lesion was no longer evident (fig. $1 \mathrm{c}$ ). At the 5 th evaluation (February 2005), the pelvic lesion was no longer detectable by ultrasound, and therefore a control evaluation was performed by CT scan (March 2005). This scan showed that the tumor had decreased to $5.5 \times 4.6$ $\times 4.1 \mathrm{~cm}$ in size, and demonstrated further remission. The 6 th evaluation (July 2005), again performed by CT scan, showed that the uterine tumor had decreased to $5.5 \times 4.3 \times 3.6 \mathrm{~cm}$.

The most recent CT scans revealed that the uterine tumor had decreased in size to $5.0 \times 3.5 \times 3.4 \mathrm{~cm}$ in November 2005 (fig. $1 \mathrm{~d}$ ) and had shrunk to $4.8 \times 3.5 \times 3.2 \mathrm{~cm}$ in April 2006. No new metastasis of the liver was detected. As of April 2006, fulvestrant therapy was ongoing and the patient was asymptomatic, generally in good health, and no serious adverse events had occurred. She experienced a weight gain of $32 \mathrm{~kg}$ during fulvestrant treatment, but had previously lost $14 \mathrm{~kg}$ during radiotherapy. This is representative of the patient returning to her former weight. Moreover, a Karnofsky performance index of $90 \%$ was maintained throughout fulvestrant treatment, reflecting the patients' good quality of life.

\section{Discussion}

Uterine cancer usually presents as stage I disease and can be managed effectively by extrafascial total hysterectomy with bilateral salpingo-oophorectomy [12]. However, the prognosis for advanced or recurrent uterine cancer is poor [13]. As uterine tumors arise from hormone-responsive tissue, some of these malignancies express hormone receptors and are therefore potentially responsive to endocrine therapy. Whilst some small studies [14-16] and phase II trials [17] have been published investigating this therapeutic avenue, there remains a need for further investigations.

In this case study, we demonstrated the successful treatment of metastatic uterine cancer with fulvestrant - a new ER antagonist with no agonist effects. At the time of fulvestrant administration, our patient also had a hepatic lesion. As has previously been noted, the liver is a common site of metastases for women with uterine cancer [18]. Our patient responded well to treatment for over 2 years, experiencing no serious adverse events and a stable Karnofsky performance index of $90 \%$. The decision not to administer progestins was based 
Fig. 1. Abdominal CT scan images showing response to treatment: a initial scan (September 2003); b pre-fulvestrant stable pelvic tumor with suspected hepatic metastases (February 2004); c effect of 8 months of fulvestrant treatment (November 2004), stable pelvic tumor and hepatic metastases no longer detectable; d effect of 21 months of fulvestrant treatment (November 2005), remission of the pelvic tumor, hepatic metastases not detectable.
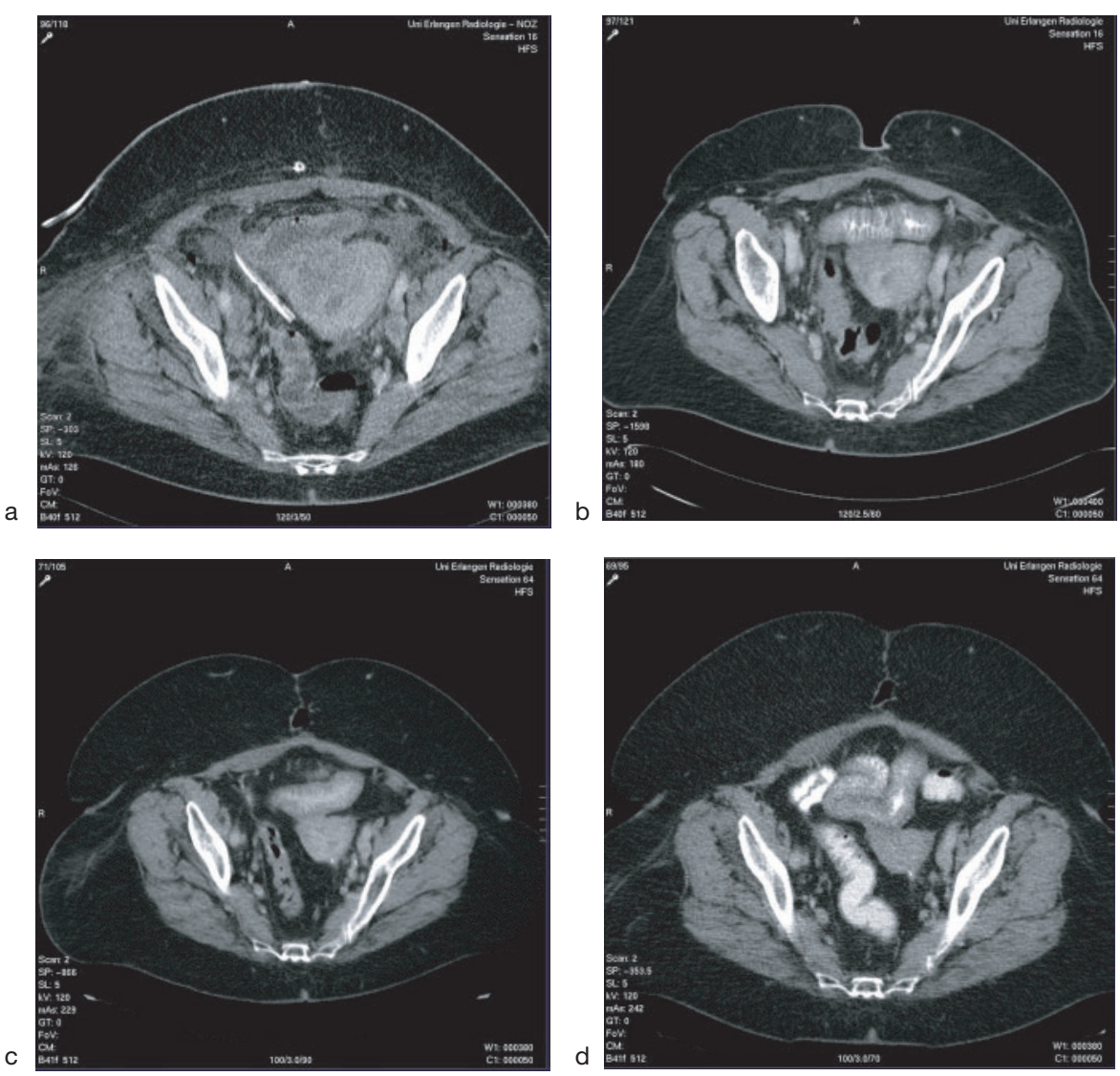

mainly on their tolerability profile. These agents are associated with weight gain $[19,20]$ and may increase risk of thrombosis, particularly in those with other risk factors [21]. Response rates in patients with metastatic uterine cancer are also generally low [22]. Our patient had pre-existing hypertension and varicosis and was also overweight. Therefore, she was not considered suitable for progestin therapy. Although this was an off-label use, fulvestrant was chosen as this patient's first-line hormonal treatment based on the positive experience we had of using fulvestrant during the AGO Uterus-5 study. This is an open, multicenter phase II study assessing the efficacy and tolerability of fulvestrant $250 \mathrm{mg} / \mathrm{month}$ in the treatment of recurrent or metastatic endometrial carcinoma (www.ago-online.org; www.clinicaltrial.gov/ct/show/NCT00006903? order $=1$ ).

Some endocrine agents, e.g. tamoxifen, have weak estrogen agonist properties that can cause endometrial cell proliferation [23], perhaps making them less attractive options for the treatment of uterine cancer $[24,25]$. Fulvestrant, in contrast, lacks estrogen agonist activity [26], and has been shown to block the growth of the endometrium in ovariectomized estrogen-treated monkeys [27]. Moreover fulvestrant inhibits the growth of EnCa101 carcinoma xenografts (derived from an ER-positive, well-differentiated human endometrial tumor) implanted in thymectomized mice [28], which gave an early suggestion of its potential in this setting.
Fulvestrant also offers the potential of durable efficacy, with phase III studies showing a median duration of response of 16.7 months in patients with tamoxifen-resistant advanced breast cancer [10]. The durable efficacy of fulvestrant observed in such clinical trials [10] is comparable with the prolonged response observed in our study. Additionally, fulvestrant has been shown to provide a similar quality of life to tamoxifen and anastrozole [10, 29]. Also, in line with clinical trial data [10, 29], fulvestrant was well tolerated by our patient. The restoration of the patient's former weight has not previously been reported.

2 phase II trials are currently underway investigating the activity of fulvestrant in endometrial carcinoma, one being the previously mentioned AGO Uterus-5 study. The Gynecologic Oncology Group (GOG) is also investigating the activity of fulvestrant in patients with recurrent, persistent or metastatic ERpositive and ER-negative endometrial carcinoma ( $w w w . c l i n i-$ caltrials.gov/ct/show/NCT00006903). In addition, several phase III trials in patients with advanced breast cancer are ongoing that utilize fulvestrant loading-dose regimens $(500 \mathrm{mg}$ on day 0 , $250 \mathrm{mg}$ on days 14 and $28,250 \mathrm{mg} / \mathrm{month}$ thereafter), which may result in a shorter time to response [30]. Should such regimens prove effective and well tolerated, they may also be considered in the metastatic uterine cancer setting.

The successful use of fulvestrant in an endocrine therapynaïve patient was reported here. Although chemo- and radio- 
therapy had failed to delay progression, fulvestrant treatment resulted in remission of the primary tumor and hepatic metastasis, a substantial period of stable disease and a good quality of life, as reported by the patient. Fulvestrant has previously been shown to be effective in the treatment of patients with advanced breast cancer [31] and is currently licensed for use in patients with breast cancer recurrence or progression following antiestrogen failure. Should the results of ongoing trials be positive, fulvestrant may offer patients with hormone recep- tor-positive metastatic uterine cancer an exciting new treatment option.

\section{Acknowledgement}

The authors would like to thank Catherine Hoare, $\mathrm{PhD}$ from Complete Medical Communications, who provided medical writing support funded by AstraZeneca.

\section{References}

1 Parker SL, Tong T, Bolden S, Wingo PA: Cancer statistics, 1997. CA Cancer J Clin 1997;47:5-27.

2 DiSaia PJ, Creasman WT: Management of endometrial adenocarcinoma stage I with surgical staging followed by tailored adjuvant radiation therapy. Clin Obstet Gynaecol 1986;13:751-765.

3 Elit L, Hirte H: Novel strategies for systemic treatment of endometrial cancer. Expert Opin Investig Drugs 2000;9:2831-2853.

4 National Comprehensive Cancer Network: Uterine Cancers. Clinical Practice Guidelines in Oncology v.1.2006. www.nccn.org/professionals/physician_gls/ PDF/uterine.pdf.

5 Hanf V, Gunthert AR, Emons G: Endometrial cancer. Onkologie 2003;26:429-436.

6 Kneale BL: Adjunctive and therapeutic progestins in endometrial cancer. Clin Obstet Gynaecol 1986; 13:789-809.

7 Podratz KC: Hormonal therapy in endometrial carcinoma. Recent Results Cancer Res 1990;118: 242-251.

8 Chan S: A review of selective estrogen receptor modulators in the treatment of breast and endometrial cancer. Semin Oncol 2002;29:129-133.

9 Gadducci A, Cosio S, Genazzani AR: Use of estrogen antagonists and aromatase inhibitors in breast cancer and hormonally sensitive tumors of the uterine body. Curr Opin Investig Drugs 2004;5: 1031-1044.

10 Robertson JF, Osborne CK, Howell A, Jones SE, Mauriac L, Ellis M, Kleeberg UR, Come SE, Vergote I, Gertler S, Buzdar A, Webster A, Morris C: Fulvestrant versus anastrozole for the treatment of advanced breast carcinoma in postmenopausal women - a prospective combined analysis of two multicenter trials. Cancer 2003;98:229-238.

11 Günthert AR, Ackermann S, Kiesel L, Steiner E, Schröder W, Camara O, Mallman P, Emons G: Phase II study of weekly docetaxel in patients with recurrent or metastatic endometrial cancer, AGO Uterus-4. J Clin Oncol (Meeting Abstracts) 2005; 23:abstr 5083
12 Carter J, Pather S: An overview of uterine cancer and its management. Expert Rev Anticancer Ther 2006;6:33-42.

13 Baekelandt M: Hormonal treatment of endometrial carcinoma. Expert Rev Anticancer Ther 2002; 2:106-112.

14 Munster PN, Buzdar A, Dhingra K, Enas N, Ni L, Major M, Melemed A, Seidman A, Booser D, Theriault R, Norton L, Hudis C: Phase I study of a third-generation selective estrogen receptor modulator, LY353381.HCL, in metastatic breast cancer. J Clin Oncol 2001;19:2002-2009.

15 Dardes RC, Bentrem D, O'Regan RM, Schafer JM, Jordan VC: Effects of the new selective estrogen receptor modulator LY353381. $\mathrm{HCl}$ (arzoxifene) on human endometrial cancer growth in athymic mice. Clin Cancer Res 2001;7:4149-4155.

16 Litherland S, Jackson IM: Antiestrogens in the management of hormone-dependent cancer. Cancer Treat Rev 1988;15:183-194.

17 McMeekin DS, Gordon A, Fowler J, Melemed A, Buller R, Burke T, Bloss J, Sabbatini P: A phase II trial of arzoxifene, a selective estrogen response modulator, in patients with recurrent or advanced endometrial cancer. Gynecol Oncol 2003;90:64-69.

18 Heyer H, Ohlinger R, Arndt D, Belau A, Nehmzow M, Hosten N, Kohler G: Selective pretreatment diagnostic imaging for detecting remote metastases in patients with endometrial cancer. Onkologie 2006;29:85-89.

19 Davila E, Vogel CL, East D, Cairns V, Hilsenbeck S: Clinical trial of high-dose oral medroxyprogesterone acetate in the treatment of metastatic breast cancer and review of the literature. Cancer 1988;61: 2161-2167.

20 Medroxyprogesterone and palliative care: new indication. No impact on quality of life. Prescrire Int 2001;10:3-4.

21 Brema F, Queirolo MA, Canobbio L, Bruzzi P, Puntoni R, Campora E, Rosso R: Hematologic parameters during treatment with high-dose medroxyprogesterone acetate. Tumori 1981;67:125-128.

22 Quinn MA: Hormonal treatment of endometrial cancer. Hematol Oncol Clin North Am 1999;13: 163-187.
23 Fornander T, Rutqvist LE, Cedermark B, Glas U, Mattsson A, Skoog L, Somell A, Theve T, Wilking $\mathrm{N}$, Askergren J: Adjuvant tamoxifen in early-stage breast cancer: effects on intercurrent morbidity and mortality. J Clin Oncol 1991;9:1740-1748.

24 Mourits MJ, de Vries EG, Willemse PH, Ten Hoor KA, Hollema H, van der Zee AG: Tamoxifen treatment and gynecologic side effects: a review. Obstet Gynecol 2001;97:855-866.

25 Van Leeuwen FE, Benraadt J, Coebergh JW, Kiemeney LA, Gimbrere CH, Otter R, Schouten LJ, Damhuis RA, Bontenbal M, Diepenhorst FW: Risk of endometrial cancer after tamoxifen treatment of breast cancer. Lancet 1994;343:448-452.

26 Addo S, Yates RA, Laight A: A phase I trial to assess the pharmacology of the new oestrogen receptor antagonist fulvestrant on the endometrium in healthy postmenopausal volunteers. Br J Cancer 2002;87:1354-1359.

27 Dukes M, Miller D, Wakeling AE, Waterton JC: Antiuterotrophic effects of a pure antioestrogen, ICI 182,780: magnetic resonance imaging of the uterus in ovariectomized monkeys. J Endocrinol 1992;135:239-247.

28 O'Regan RM, Cisneros A, England GM, MacGregor JI, Muenzner HD, Assikis VJ, Bilimoria MM, Piette M, Dragan YP, Pitot HC, Chatterton R, Jordan VC: Effects of the antiestrogens tamoxifen, toremifene, and ICI 182,780 on endometrial cancer growth. J Natl Cancer Inst 1998;90:1552-1558.

29 Howell A, Robertson JFR, Abram P, Lichinitser MR, Elledge R, Bajetta E, Watanabe T, Morris C, Webster A, Dimery I, Osborne CK: Comparison of fulvestrant versus tamoxifen for the treatment of advanced breast cancer in postmenopausal women previously untreated with endocrine therapy: a multinational, double-blind, randomized trial. J Clin Oncol 2004;22:1605-1613.

30 Dodwell D: Time to response - a comparison of fulvestrant with anastrozole. Eur Jour Cancer Suppl 2005;3:79(abstr 280).

31 Hoffman MA, Khan A: Durable response of metastatic endometrial carcinoma to treatment with fulvestrant (Faslodex ${ }^{\circledR}$ ) after prior progestin and anastrozole therapy. Gynecol Oncol 2006;100:439-441. 